Article

\title{
Profile of Female Sterilization in Brazil
}

\author{
Ernesto F. L. Amaral (D) \\ Department of Sociology, Texas A\&M University, College Station, TX 77843, USA; amaral@tamu.edu
}

Received: 15 May 2019; Accepted: 22 September 2019; Published: 25 September 2019

check for updates

\begin{abstract}
Background: This study analyzes the profile of female sterilization in Brazil by age, parity, type of delivery, place of delivery, color/race, region of residence, years of schooling, marital status, number of unions, and desired number of children reported by women; (2) Methods: The descriptive analysis is based on the most recent Brazilian database on reproductive health: the 2006 Brazilian National Survey on Demography and Health of Women and Children (PNDS). This dataset has information on the history of pregnancies with live births from January 2001 to July 2007; (3) Results: The study suggests that (a) women with high levels of sterilization, high percentages of more than one pregnancy in the period, and larger parity than the desired number of children tend to have high parity, be black, brown, or indigenous, reside in the North or Northeast, have low levels of education, and have two or more unions; and (b) women with high levels of sterilization, low percentages of more than one pregnancy in the period, and lower parity than the desired number of children tend to have cesarean sections, give birth utilizing private health care obtained through a private insurance plan or direct out-of-pocket payment at private hospitals, and be married. (4) Conclusions: The 1997 family planning law could be altered in order to allow female sterilization in conjunction with childbirth, as a way to attend the demand of Brazilian women in public hospitals. Policies are necessary not only to regulate the public sector, but also to aim better services at private institutions. Female sterilization should be discussed in the context of fertility below the replacement level, as one of its associated factors.
\end{abstract}

Keywords: contraceptive agents; female; sterilization; reproductive health; Brazil

\section{Introduction}

The decline of fertility in Brazil is associated with the rise in the use of modern contraception (Berquó et al. 2008; Leone and Hinde 2005; Perpétuo 1998; Perpétuo and Wajnman 2003; Perpétuo and Wong 2009). Total fertility rate (TFR) fell from 6.28 children per woman in 1960 to 1.90 in 2010 (IBGE 2012). The country is marked by significant regional differences in terms of the timing, pace, and scale of fertility decline (Potter et al. 2002, 2010). The TFR in 2010 was 2.47 in the North, 2.06 in the Northeast, 1.7 in the Southeast, 1.78 in the South, and 1.92 in the Central-West region (IBGE 2012). In terms of contraception, pills and female sterilization are the most utilized methods (Amorim et al. 2008; Cavenaghi and Alves 2009; Janowitz et al. 1985; Perpétuo and Wong 2009; Potter 1999; Vieira 2007). Based on data from the 1996 and 2006 Brazilian National Survey on Demography and Health of Women and Children (PNDS), female sterilization declined from 38.5 percent to 25.9 percent (Perpétuo and Wong 2009). The number of women who use pills rose from 23.1 percent in 1996 to 27.4 percent in 2006. The use of condoms increased from 4.6 to 13 percent during the period. The percentage of women who were married to men who had obtained a vasectomy rose from 2.8 to 5.1 percent. The use of other modern methods (IUD, diaphragm, injections, etc.) rose from three to seven percent throughout the same period. The practice of withdrawal decreased from three to 2.1 percent. The number of women who utilized periodic abstinence fell from 2.9 to one percent between 1996 and 2006. Finally, 
the number of women who did not use any method declined from 22.1 percent to 18.4 percent in the period (Perpétuo and Wong 2009).

The federal government did not implement public policies to reduce fertility, change female reproductive behavior, or increase the use of contraception (Fonseca Sobrinho 1993). The country has inadequate public services for sexual and reproductive health, predominance of the private sector, delayed and inappropriate use of contraceptives, insufficient medical care and reversible methods, a high proportion of unwanted pregnancies, and social inequality affecting access to contraception (Bilac and Rocha 1998; Giffin and Costa 1999; Miranda-Ribeiro and Simão 2009; Schor et al. 2000; Vieira 2007; Vieira and Souza 2009). Only in 1997 did the government implement a family planning law. One of the goals of the law \#9263 from 12 January 1996 was to enable sterilization in public hospitals, but with restrictions for surgeries during cesarean deliveries, childbirth, and abortion (Brasil 1996). This law states that "The surgical sterilization of a woman is forbidden during childbirth or abortion, except for health reasons caused by previous successive cesarean deliveries" (Law No. 9263, Article No. 10, Paragraph No. 2 from 12 January 1996. Article 10 was vetoed until 19 August 1997. Document available on: http://www.planalto.gov.br/ccivil_03/LEIS/L9263.htm) (Brasil 1996). Furthermore, the law states that female and male sterilizations are permitted only for persons above the age of 25 years or for persons with at least two children born alive. Sterilizations may be performed no less than 60 days after the request, so there is time for counseling by a public multidisciplinary health group. Regulations of the 1997 law appear to restrain the provision of this surgical procedure in public hospitals (Osis et al. 2009).

A series of academic studies investigated factors associated to the decision of women to get sterilized, as well as outcomes following this surgical procedure in Brazil (Cunha et al. 2007; Curtis et al. 2006; Fernandes et al. 2001; Hopkins 2009; Ludermir et al. 2009; Machado et al. 2005; Perpétuo and Wong 2009; Vieira et al. 2005; Vieira 2007). Some studies identified evidence of regret after female sterilization (Curtis et al. 2006; Fernandes et al. 2001; Ludermir et al. 2009; Machado et al. 2005; Vieira 2007). Other studies evidenced a frustrated demand for female sterilization (Caetano and Potter 2004; Costa et al. 2006; Lacerda et al. 2005; Osis et al. 2009; Potter et al. 2003). Local governments have insufficient public infrastructure and human resources to supply female sterilization in their municipalities (Osis et al. 2009). Extreme inequality in the access to female sterilization exists between the public and private sectors (Costa et al. 2006). Despite the legal impediments from the 1997 family planning law, female sterilization is still performed in conjunction with childbirths and cesarean sections in private hospitals (Barbosa and Knauth 2003; Berquó 1999; Berquó and Cavenaghi 2003; Berquó et al. 2008; Carvalho et al. 2007; Molina 1999; Perpétuo and Wong 2009). One study suggested updating the family planning law to allow female sterilization after vaginal delivery (Potter et al. 2003). The prevalence of female sterilization is higher among older women with higher parity, fewer years of education, less educated spouses or companions, as well as among black and indigenous people (Amorim et al. 2008). Women with high levels of education get sterilized after they reach their ideal number of children, as a result of planning for a specific number of offspring through the use of temporary contraceptives (Perpétuo and Wong 2009). Poorly educated women get sterilized without having used another contraceptive method, after reaching more than the ideal number of children while experiencing shorter birth intervals, demonstrating an increased incidence of regret for the total number of children ever born (Perpétuo and Wong 2009). The option for sterilization seems to be a result of higher fertility among women who started childbearing early in life (Osis et al. 2003). Differentials in the risk of sterilization also take into account marital status (married, cohabiting/in union, not in union) (Godecker et al. 2001) and number of unions (Leone and Hinde 2005).

Female sterilization is an important research topic in the area of reproductive health in Brazil due to its correlations with several women's characteristics, government regulations, and institutional practices. However, only 31 papers about female sterilization were published between 2000 and 2010 (out of 6061 publications) in the main public health and medical journals available in the Scientific 
Electronic Library Online (SciELO) (Minella 2012). This paper conducts a descriptive analysis of the profile of female sterilization in Brazil between January 2001 and July 2007.

This study provides an overview of the characteristics of women who are sterilized, using a nationally representative survey. Few studies accomplished this task, because of the lack of data on female sterilization for the whole country. Most studies on female sterilization in Brazil utilize qualitative approaches. These studies have important findings, such as the ones discussed above. However, they are not representative to the whole country in statistical terms. The 2006 PNDS is the most recent national survey with detailed reproductive health information for Brazilian women. As cited before, one chapter analyzed sterilization trends using this survey (Perpétuo and Wong 2009). The present paper goes beyond that study by analyzing other variables not previously linked to sterilization using PNDS. I explore this nationally representative database to give a unique overview of sterilization variations by a series of women's characteristics: age at sterilization, parity at delivery, type of delivery, place of delivery, color/race, region of residence, years of schooling, marital status, and number of unions. More specifically, an important contribution of this paper is the comparison between the number of children ever born (parity) and the desired number of children reported by women for several subgroups of the population. This analysis also considers sterilization rates within these subgroups. Using this method, it is possible to verify which characteristics of women are more likely to contribute to lower levels of fertility than those desired by women themselves. I also develop a unique investigation of this dataset by estimating a series of cumulative percentage distributions of sterilized women by age and the variables previously mentioned. These strategies were not previously developed with PNDS and provide a deeper understanding of the profile of female sterilization in Brazil. The next section provides more information about the database and selected variables for analysis.

\section{Data and Methods}

This study investigates the most recent database on reproductive health in Brazil: the 2006 Brazilian National Survey on Demography and Health of Women and Children (PNDS). Similar surveys were implemented as Demographic and Health Surveys (DHS) by the "Sociedade Civil Bem-Estar Famliar no Brasil" (BEMFAM) in 1986 (https://dhsprogram.com/what-we-do/survey/survey-display-2.cfm), 1991 (https://dhsprogram.com/what-we-do/survey/survey-display-40.cfm), and 1996 (https://dhsprogram. com/what-we-do/survey/survey-display-85.cfm), as part of the DHS Program. In 2006, PNDS was conducted after a public bidding promoted by the Secretary of Science, Technology, and Strategic Inputs of the Brazilian Ministry of Health (Sctie/MS), in a partnership with the United Nations Educational, Scientific, and Cultural Organization (UNESCO) (http://bvsms.saude.gov.br/bvs/pnds/index.php). The implementing organization was the Brazilian Center of Analysis and Planning (CEBRAP) (Brasil 2009). A detailed nationally representative survey on reproductive health has not been conducted in Brazil since 2006.

Concerning female sterilization, several important qualitative studies have been performed about sterilization in Brazil, as discussed in the previous section. However, the present study does not conduct a qualitative or mixed methods research of present trends of sterilization in Brazil. The goal is to focus on the 2006 PNDS by exploring sterilization rates and desired number of children by a series of variables not previously investigated with this database.

The analysis utilizes 2006 PNDS data and concerns women between 15 and 49 years of age at the time of the interview, who had experienced live births beginning in January 2001. The databases come from questionnaires with information on households/individuals $(n=56,365)$, women $(n=15,575)$, history of pregnancies since January $2001(n=6833)$, and history of all children born alive $(n=27,477)$. The aggregation of variables from these different databases considers household, woman, and child identifications.

The database with information on households/individuals provides date of birth and years of schooling. The dataset on women includes traditional and modern contraceptive methods currently 
being used, month and year that the female sterilization took place, total number of children ever born alive, color/race, region of residence, marital status, number of marriages/unions, and ideal number of children (desired number of children by women). PNDS also collects data on history of pregnancies since 2001, including the month and year of delivery/childbirth or end of pregnancy. Information on pregnancies also provides cases which did not result in live births. The database about children born alive has information on type of delivery and place of delivery.

Based on the date of birth of each woman, date of sterilization and date of delivery/childbirth, it is possible to estimate the age of each woman at the time of sterilization. PNDS provides information on current number of children ever born (parity), as well as birth order (month and year of each delivery/childbirth). The combination of this set of variables is utilized to estimate the parity at the time of each delivery. The history of pregnancies allows the estimation of the number of pregnancies in the period. The analysis excludes women who did not remember their own date of birth, date of sterilization, or date of delivery/childbirth. In this study, parity at delivery, type of delivery, and place of delivery relate to information from the last birth. Thus, the unit of analysis reports on women with live births between January 2001 and July 2007 and the final sample includes 4580 women. Although this study utilizes the 2006 PNDS, pregnancies in the database are reported up to July 2007.

Information on female sterilization is used as the main variable of analysis, considering the month and year of sterilization. The variables used to explore the profile of female sterilization are (1) woman's age in years at the moment of sterilization (15-24, 25-29, 30-34, 35-49), (2) parity at delivery $(1,2,3,4+)$, calculated with information about number of children ever born and birth order, (3) type of delivery: vaginal birth or cesarean section, (4) place of delivery: home, public hospital with publicly-funded health care ("Sistema Único de Saúde"-SUS), hospital with private health insurance ("convênio"), public health center, or private hospital with direct out-of-pocket payment, (5) color/race of the woman: white ("branca"), black ("preta"), brown ("parda"), yellow ("amarela"), indigenous ("indígena"), (6) region of residence: North, Northeast, Southeast, Central-West, or South, (7) years of schooling: 0-3 (less than first phase of primary completed), 4-7 (less than second phase of primary completed), 8-10 (primary completed), 11+ (at least secondary completed), (8) marital status: married, cohabiting (in union), or not in union, and (9) number of marriages/unions. Information on region of residence, years of schooling, marital status and number of marriages/unions might change over time. However, the database does not provide information for this variation, but only addresses the situation at the time of the interview.

In relation to the color/race variable, according to the 2010 Demographic Census, out of a population of 190,755,799 inhabitants, the white category represented 47.51 percent of the Brazilian population, black 7.52 percent, brown 43.42 percent, yellow 1.10 percent, indigenous 0.43 percent, and no color/race information 0.02 percent (Table 2093 in https://sidra.ibge.gov.br/tabela/2093). Brazilian demographers conducting studies over time usually combine color/race categories of black ("preta") and brown ("parda") into non-white ("negra"). This is done because some people who in previous decades used to classify themselves as brown are now becoming more aware of race identity and self-classifying as black (Carvalho et al. 2003, 2004; Wood and Carvalho 1994). If a researcher intends to make comparisons of color/race trends through time, it would be more appropriate to combine black and brown categories. Since the yellow and indigenous groups represent small percentages of the Brazilian population, some researchers exclude them from their studies. However, the current analysis about female sterilization is utilizing only one year of data. Furthermore, the black population on average has a lower socioeconomic status than the brown population, as detailed below with income data. Thus, the intention is to explore the disaggregated color/race variable to provide a more detailed variation of sterilization trends by all available categories.

An important aspect of the Brazilian society is income inequality by color/race. It would have been interesting to estimate variations of sterilization rates by economic indicators, as well as by interactions of economic indicators and color/race. Based on the 2010 Brazilian Census, the national average of monthly nominal earnings from all jobs was 1256.00 Brazilian Reais (755.81 Dollars in 
2010) for people with at least ten years of age with an occupation at the time of the Census reference week. Earnings varied significantly by color/race: 1622.75 Brazilian Reais for the white population, 866.23 for black, 872.57 for brown, 1725.59 for yellow, and 602.64 for indigenous (Table 3577 in https://sidra.ibge.gov.br/tabela/3577). Considering any source of income, even if people did not have an occupation, the variation still persisted: 1340.48 for national average, 1750.77 for white, 906.56 for black, 911.58 for brown, 1782.82 for yellow, and 783.21 for indigenous (Table 3597 in https://sidra.ibge.gov.br/tabela/3597). People who tend to utilize more public health services are from lower socioeconomic groups, which have higher proportions of black and brown population. The population who usually utilizes more private health services are from wealthier socioeconomic groups which have higher proportions of white population.

However, PNDS does not have a direct measure of earnings or social class. It is possible to estimate a social class indicator using an economic scale with 46 levels, used as a proxy for earnings (Perpétuo and Wong 2009). This scale is based on information about educational attainment of the household head, presence of monthly-paid housekeeper, as well as possession of color television, radio, bathroom, vehicle, dishwasher, VCR player and/or DVD player, and fridge. This social class indicator is a valuable measure but it can be easily criticized by the decisions of including or excluding some variables to estimate its values. As a way to deal with this limitation, sterilization rates are estimated by years of schooling of women (described above), which is also utilized as a proxy for socioeconomic indicator by Perpétuo and Wong (2009).

Averages of ideal number of children were also estimated for the categories of the variables listed above. The question format in the PNDS questionnaire was implemented differently depending on whether women had children at the time of the interview. For women who had at least one living child at the time of the interview, they were asked how many children they would have had if it was possible to go back to the time when they had no children and they could choose the number of children to have for their whole life. Women who were pregnant for the first time or had no living child were asked how many children they would have if it was possible to choose the number of children to have for their whole life. Throughout this paper, the terms "ideal number of children" and "desired number of children" are used interchangeably.

Before constructing tables and figures, the sample design (strata and conglomerate) and the expansion factor of women (weight) were defined with the "svyset" command in Stata. The strata are the combination of the five major regions (North, Northeast, Southeast, Central-West, and South) and household situation (urban and rural). The primary sampling unit (PSU) is formed by the census tracts (conglomerate).

\section{Results}

The pregnancies analyzed in this study refer to the period from January 2001 to July 2007. The percentage of women sterilized is 15.3 percent (Table 1). Within this time period, there is a higher percentage of women who had more than one pregnancy among the sterilized (26.0 percent), compared to those who are not sterilized (18.2 percent). Sterilized women have greater parity (3.0) than the desired number of children (2.4). Women who are not sterilized did not yet reach their desired number of children (2.0), compared to the observed parity (1.8). Moreover, Table 1 indicates that the levels of sterilization increase with women's age. The younger women experienced the highest percentages of more than one pregnancy in the period. Women with at least 25 years of age have a higher parity than the desired number of children. Finally, the percentage sterilized and the proportion of women with more than one pregnancy in the period increases with parity at the time of delivery of the last birth. 
Table 1. Distribution of women by sterilization situation, age at the moment of sterilization, and parity at the moment of the last delivery, Brazil, January 2001 to July 2007.

\begin{tabular}{lccccc}
\hline \multicolumn{1}{c}{ Categories } & $\begin{array}{c}\text { Percent of } \\
\text { Women }\end{array}$ & $\begin{array}{c}\text { Percent of } \\
\text { Sterilization }\end{array}$ & $\begin{array}{c}\text { Percent of More } \\
\text { than One Pregnancy }\end{array}$ & Parity & $\begin{array}{c}\text { Ideal Number } \\
\text { of Children }\end{array}$ \\
\hline Total & $\mathbf{4 5 8 0 ^ { * }}$ & - & $\mathbf{1 9 . 4 3}$ & $\mathbf{1 . 9 7}$ & $\mathbf{2 . 0 2}$ \\
$\quad$ Sterilized & 15.32 & - & 26.00 & 2.95 & 2.35 \\
$\quad$ Not sterilized & 84.68 & - & 18.24 & 1.80 & 1.96 \\
\hline Age at sterilization & & & & & \\
15-24 & 52.87 & 6.40 & 21.87 & 1.58 & 1.84 \\
$25-29$ & 23.35 & 21.91 & 20.71 & 2.15 & 2.03 \\
30-34 & 14.10 & 28.34 & 13.13 & 2.33 & 2.25 \\
35-49 & 9.68 & 29.17 & 12.09 & 3.18 & 2.64 \\
\hline Parity at delivery & & & & & \\
1 child & 44.66 & 0.41 & 0.00 & 1.00 & 1.79 \\
2 children & 30.70 & 20.24 & 34.36 & 2.00 & 2.04 \\
3 children & 15.99 & 35.47 & 34.60 & 3.00 & 2.28 \\
4+ children & 8.65 & 37.59 & 38.73 & 5.01 & 2.70 \\
\hline Source: 2006 Brazilian National Survey on Demography and Health of Women and Children (PNDS) * Sample size.
\end{tabular}

Table 2 illustrates the distribution of women by type and place of delivery of the last child. Between 2001 and 2007, 55.1 percent of women had vaginal births, and 44.9 percent experienced cesarean sections. The percentage of sterilization among women who had cesarean deliveries (24.4 percent) is much higher than among women who had vaginal deliveries (7.9 percent). The percentage of women with more than one pregnancy in the period is higher among those who had vaginal births compared to women who had cesarean births. Parity is higher than the desired number of children among women who delivered vaginally. In the case of women who had cesarean births, the ideal number of children (2.1) is higher than the observed parity (1.8 children).

Table 2. Distribution of women by type and place of delivery, Brazil, January 2001 to July 2007.

\begin{tabular}{|c|c|c|c|c|c|}
\hline Categories & $\begin{array}{l}\text { Percent of } \\
\text { Women }\end{array}$ & $\begin{array}{l}\text { Percent of } \\
\text { Sterilization }\end{array}$ & $\begin{array}{l}\text { Percent of } \\
\text { more than One } \\
\text { Pregnancy }\end{array}$ & Parity & $\begin{array}{l}\text { Ideal Number } \\
\text { of Children }\end{array}$ \\
\hline \multicolumn{6}{|l|}{ Type of delivery } \\
\hline Vaginal & 55.14 & 7.91 & 22.68 & 2.11 & 1.98 \\
\hline Cesarean & 44.86 & 24.42 & 15.44 & 1.81 & 2.07 \\
\hline \multicolumn{6}{|l|}{ Place of delivery } \\
\hline At home & 1.43 & 4.36 & 33.69 & 3.20 & 2.21 \\
\hline Public hospital (SUS) & 75.21 & 13.83 & 21.03 & 2.03 & 2.01 \\
\hline Health insurance ("convênio") & 15.36 & 17.16 & 15.09 & 1.69 & 2.03 \\
\hline Public health center & 0.10 & 0.00 & 35.09 & 1.58 & 2.13 \\
\hline Private hospital & 7.90 & 28.10 & 9.91 & 1.74 & 2.13 \\
\hline \multicolumn{6}{|l|}{ Place of vaginal delivery } \\
\hline At home & 1.43 & 4.36 & 33.69 & 3.20 & 2.21 \\
\hline Public hospital (SUS) & 49.19 & 8.49 & 22.96 & 2.12 & 1.98 \\
\hline Health insurance ("convênio") & 3.37 & 1.09 & 17.17 & 1.65 & 1.89 \\
\hline Public health center & 0.05 & 0.00 & 67.87 & 2.02 & 2.40 \\
\hline Private hospital & 1.11 & 7.97 & 10.51 & 1.71 & 1.97 \\
\hline \multicolumn{6}{|l|}{ Place of cesarean delivery } \\
\hline At home & 0.00 & - & - & - & - \\
\hline Public hospital (SUS) & 26.02 & 23.92 & 17.37 & 1.87 & 2.05 \\
\hline Health insurance ("convênio") & 12.00 & 21.67 & 14.50 & 1.70 & 2.06 \\
\hline Public health center & 0.05 & 0.00 & 0.00 & 1.10 & 1.84 \\
\hline Private hospital & 6.78 & 31.38 & 9.81 & 1.75 & 2.16 \\
\hline
\end{tabular}

Note: Type of delivery and place of delivery relate to information from the last birth. Source: 2006 Brazilian National Survey on Demography and Health of Women and Children (PNDS).

In terms of place of delivery (Table 2), 75.2 percent of women gave birth in a public hospital (SUS), 15.4 percent utilized health insurance ("convênio"), and 7.9 percent had their children at a private hospital. The highest percentage of sterilization is observed among women at private hospitals (28.1 percent), 
followed by those who used health insurance (17.2 percent), and women at public hospitals (13.8 percent). Women who gave birth at home and at public health centers presented the highest percentage of more than one pregnancy in the period, but these women represent a small proportion of the sample. In public hospitals, 21 percent of women had more than one pregnancy in the period. This percentage is lower for women utilizing health insurance, as well as for those who gave birth at private hospitals.

The analysis of place and type of delivery of the last child suggests that the majority of women have vaginal births at public hospitals (49.2 percent), followed by women with cesarean sections at public hospitals (26.0 percent). While only 3.4 percent of women gave birth vaginally with their health insurance, 12 percent of women had cesarean sections utilizing this same coverage. Moreover, only 1.1 percent of women had vaginal births at private hospitals and 6.8 percent had cesarean births at private hospitals. The highest percentages of sterilization were observed among women having a cesarean section: 31.4 percent at private hospitals; 23.9 percent at public hospitals; and 21.7 percent with health insurance. Women who had cesarean births had lower parity than the desired number of children in all the categories of place of birth.

Table 3 illustrates the distribution of women by color/race, region of residence, years of schooling, marital status, and number of unions. The percentage of women sterilized does not vary greatly by color/race. The percentage of women with more than one pregnancy in the period is higher for the indigenous category, 30.7 percent, although this group represents only 1.6 percent of women. Black (23.8 percent) and brown (21 percent) women have the highest levels of more than one pregnancy between 2001 and 2007. White and yellow women have the lowest parity, in comparison to their desired number of children. In terms of region of residence, women in the North (23.8 percent) Central-West (18.2 percent), and Northeast (17.4 percent) have the highest levels of sterilization. Women in the North and Northeast also have the highest percentages of more than one pregnancy in the period, as well as a higher parity than their desired number of children.

Table 3. Distribution of women by color/race, region of residence, years of schooling, marital status, and number of unions at the moment of interview, Brazil, January 2001 to July 2007.

\begin{tabular}{|c|c|c|c|c|c|}
\hline Categories & $\begin{array}{l}\text { Percent of } \\
\text { Women }\end{array}$ & $\begin{array}{c}\text { Percent of } \\
\text { Sterilization }\end{array}$ & $\begin{array}{l}\text { Percent of More Than } \\
\text { One Pregnancy }\end{array}$ & Parity & $\begin{array}{c}\text { Ideal Number } \\
\text { of Children }\end{array}$ \\
\hline \multicolumn{6}{|l|}{ Color/race } \\
\hline White & 35.65 & 13.68 & 15.59 & 1.88 & 2.03 \\
\hline Black & 10.21 & 14.79 & 23.77 & 2.04 & 1.80 \\
\hline Brown ("parda") & 48.55 & 16.78 & 21.01 & 2.02 & 2.08 \\
\hline Yellow & 3.97 & 12.28 & 18.80 & 1.73 & 1.81 \\
\hline Indigenous & 1.62 & 18.22 & 30.68 & 2.71 & 2.15 \\
\hline \multicolumn{6}{|l|}{ Region of residence } \\
\hline North & 9.63 & 23.78 & 29.79 & 2.45 & 2.17 \\
\hline Northeast & 27.71 & 17.35 & 24.02 & 2.06 & 2.00 \\
\hline Southeast & 40.99 & 13.26 & 16.37 & 1.85 & 1.96 \\
\hline South & 13.83 & 9.82 & 12.68 & 1.87 & 2.05 \\
\hline Central-West & 7.84 & 18.21 & 18.40 & 1.92 & 2.19 \\
\hline \multicolumn{6}{|l|}{ Years of schooling } \\
\hline $0-3$ & 10.92 & 24.59 & 28.71 & 3.04 & 2.35 \\
\hline $4-7$ & 29.54 & 16.24 & 23.94 & 2.25 & 1.99 \\
\hline $8-10$ & 26.66 & 12.34 & 19.47 & 1.75 & 1.94 \\
\hline $11+$ & 32.88 & 13.82 & 12.27 & 1.56 & 2.01 \\
\hline \multicolumn{6}{|l|}{ Marital status } \\
\hline Married & 40.82 & 18.80 & 15.06 & 1.94 & 2.17 \\
\hline Cohabiting & 44.21 & 14.81 & 24.46 & 2.06 & 1.99 \\
\hline Not in union & 14.97 & 7.33 & 16.51 & 1.80 & 1.71 \\
\hline \multicolumn{6}{|l|}{ Number of unions } \\
\hline 0 & 6.11 & 1.24 & 6.18 & 1.25 & 1.46 \\
\hline 1 & 78.14 & 14.98 & 19.15 & 1.87 & 2.04 \\
\hline $2+$ & 15.75 & 22.48 & 26.00 & 2.76 & 2.15 \\
\hline
\end{tabular}

Source: 2006 Brazilian National Survey on Demography and Health of Women and Children (PNDS).

Considering educational attainment (Table 3), women with 0-3 years of schooling have the highest percentages of sterilization (24.6 percent). These women also have the highest percentage of more 
than one pregnancy in the period (28.7 percent). Women with 4-7 years of schooling also have a high percentage of more than one pregnancy in the period (23.9 percent). Women in the two lowest education groups have higher parity than the ideal number of children. In relation to marital status, 18.8 percent of married women are sterilized, while this rate equals to 14.8 percent among cohabiting women and 7.3 percent among women not participating in a union. The highest level of more than one pregnancy between 2001 and 2007 is observed among cohabiting women (24.5 percent). These cohabiting women also present higher parity than the desired number of children. Finally, women with at least two unions have the highest level of sterilization (22.5 percent), the highest level of more than one pregnancy in the period (26 percent), and higher parity than the ideal number of children.

A way to analyze the profile of sterilization in Brazil is through the cumulative percentage distribution of sterilized women by age at sterilization. This analysis can be done for each one of the variables investigated above. In terms of parity at delivery of the last child, Figure 1 illustrates that women with at least three children at birth have the highest sterilization rates. The difference in sterilization rates between these women with at least three children and those with two children increases, as the age at the moment of sterilization increases. The low cumulative percentage of sterilized women with one child ( 0.4 percent, shown in Table 1$)$ decreases the overall cumulative percentage, which equals to 15.3 percent at 45 years of age. Women who had vaginal deliveries in the last birth have much lower cumulative sterilization percentages by age compared to women who gave last birth by cesarean section (Figure 1). This difference starts to increase at age 25, and this difference reaches the level of 16 percent at age 45 . The profile of sterilization can also be observed by analyzing the place of delivery of the last child. Women at private hospitals have the highest cumulative sterilization percentages by age. Women who gave birth at public hospitals have cumulative sterilization percentages with almost the same profile as the mean of the country, due to the fact that they represent the highest percentage of women. Women who gave birth using health insurance have lower levels of sterilization than the overall mean until the age of 38. However, these women have an increase in their cumulative percentage of sterilization in older ages. The last graph in Figure 1 shows the trends of the cumulative sterilization percentages by interacting type and place of delivery of the last child. Women who had cesarean sections at private hospitals have the highest cumulative sterilization percentages, with higher rates than all the other groups beginning at age of 28. These women show even greater increases at the age of 33. Women who delivered by cesarean section at public hospitals have cumulative sterilization percentages higher than the country's mean since the age of 25. Women who received cesarean sections using health insurance also have higher levels of sterilization than the overall mean, starting at age 38 .

Figure 2 shows the cumulative percentage distribution of sterilized women by age at sterilization, color/race, region of residence, years of schooling, marital status, and number of unions. In terms of color/race, brown and indigenous women have the highest sterilization rates across all ages. However, the percentage of indigenous women is extremely small compared to the whole sample (1.6 percent, shown in Table 3). Information on region of residence indicates much higher cumulative sterilization percentages for residents in the North, followed by residents in the Central-West and Northeast. Women with the lowest educational attainment (0-3 years of schooling) also present high cumulative sterilization percentages across all ages, and lower sterilization rates as education increases. Married women have higher sterilization rates than the overall mean beginning at age 31, and the difference of their rates in relation to the other marital status increases with age. Women who are not in unions present the lowest sterilization rates starting at age 26. Finally, women with at least two unions have the highest cumulative sterilization percentages beginning at early ages. Women with one union have a profile close to the overall mean, due to their prevalent representation in the sample (78.1 percent, noted in Table 3). Women who were never in a union have the lowest sterilization rates across all ages. 
Parity at delivery

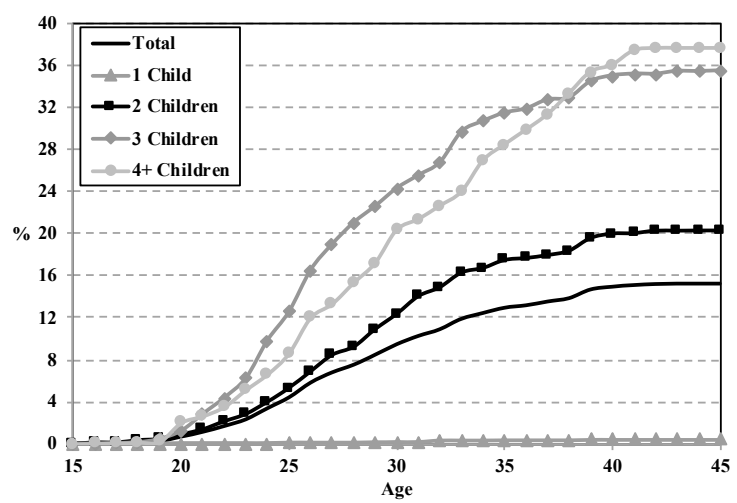

Place of delivery

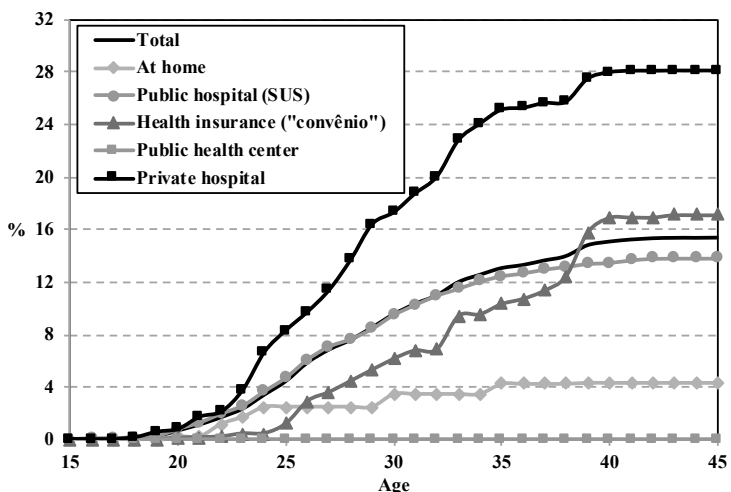

Type of delivery

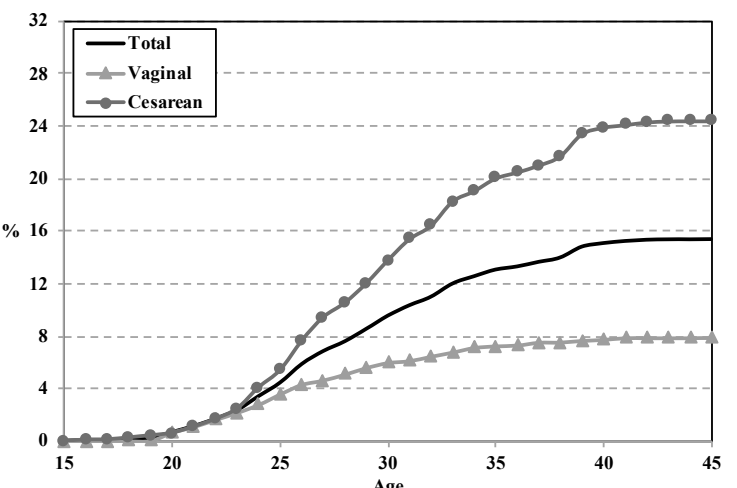

Type and place of delivery

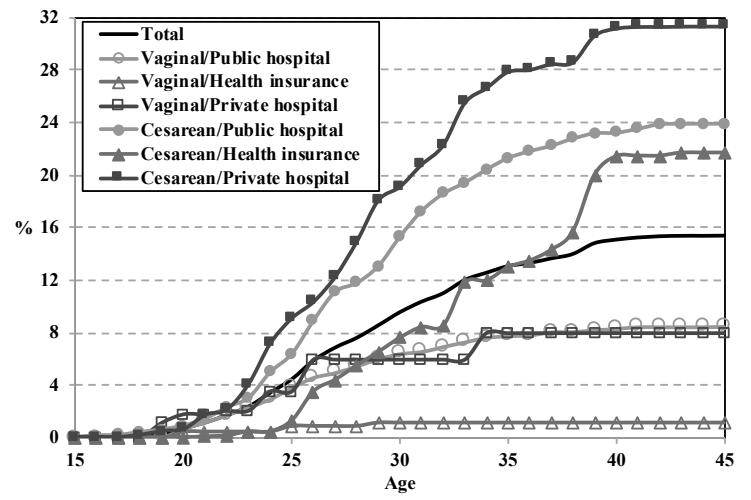

Figure 1. Cumulative percentage distribution of sterilized women by age at the moment of sterilization, Brazil, January 2001 to July 2007. Note: Parity at delivery, type of delivery, and place of delivery relate to information from the last birth. Source: 2006 Brazilian National Survey on Demography and Health of Women and Children (PNDS). 

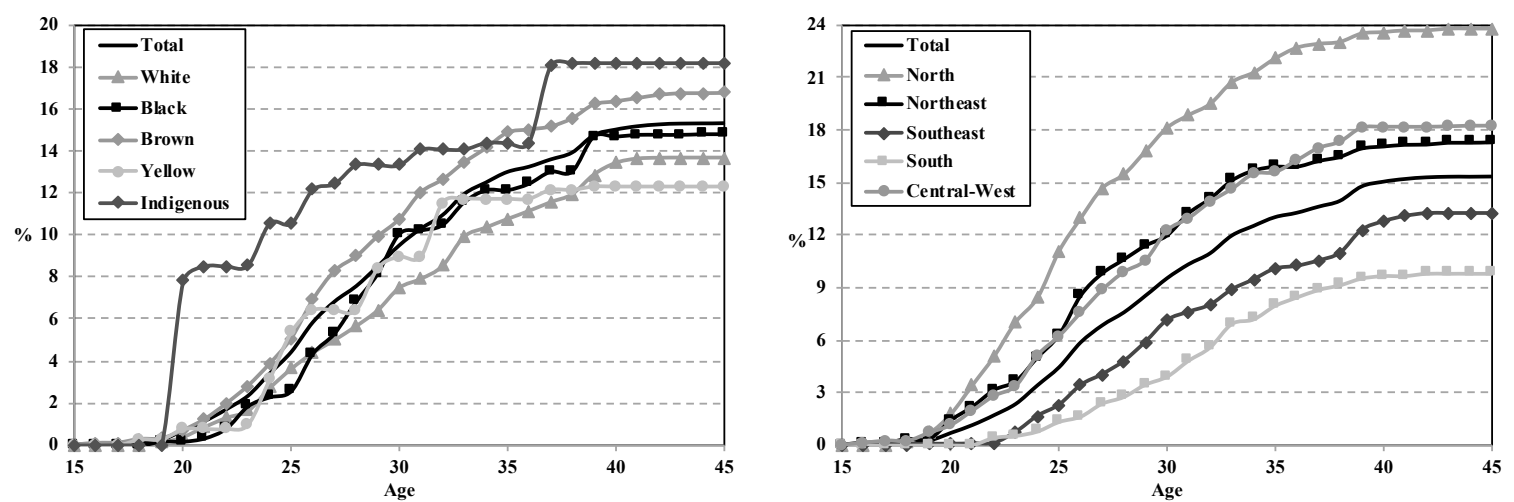

Years of schooling at interview

Marital status at interview
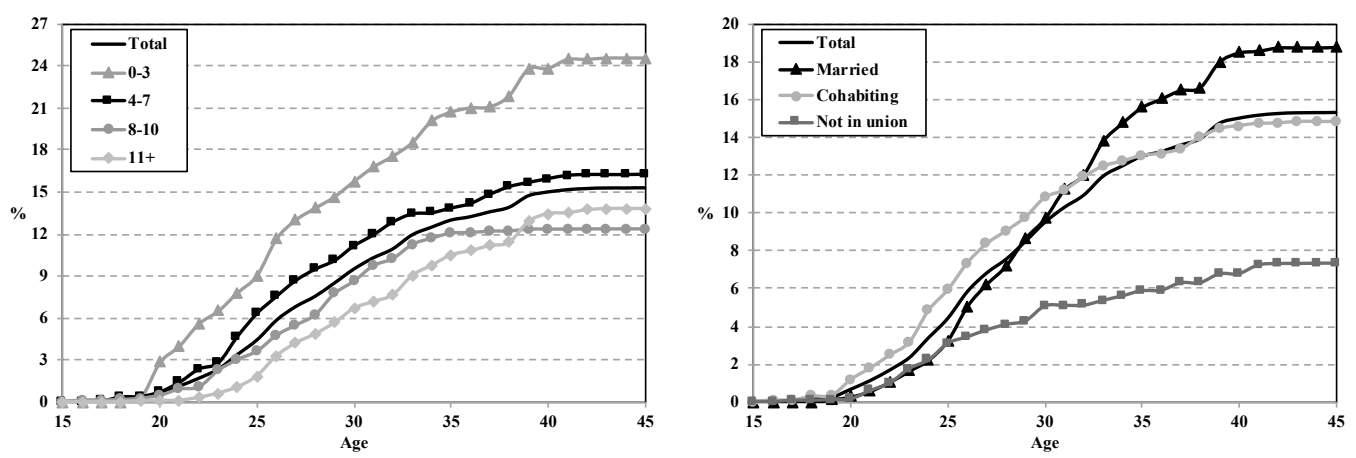

Number of unions at interview

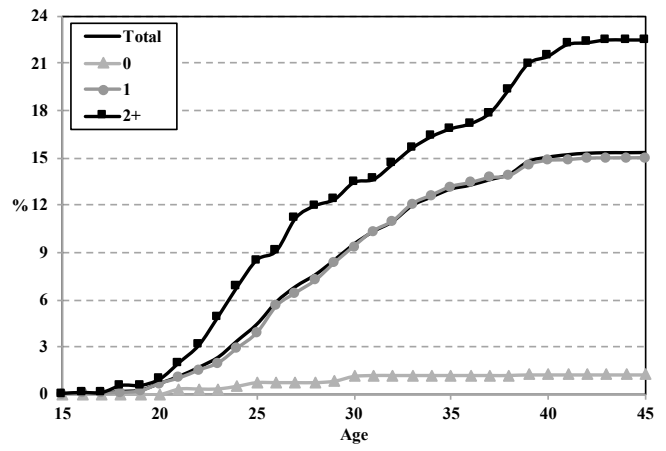

Figure 2. Cumulative percentage distribution of sterilized women by age at the moment of sterilization, Brazil, January 2001 to July 2007. Source: 2006 Brazilian National Survey on Demography and Health of Women and Children (PNDS).

\section{Discussion}

These findings may provide evidence that women with the highest percentages of more than one pregnancy in the period (indigenous, black, or brown; residents in the North; 0-3 years of schooling; and at least two unions) also have the highest cumulative sterilization percentages. The only exception that arises is for marital status. Although the highest percentage of more than one pregnancy in the period is for cohabiting women, the highest cumulative sterilization percentages are for married women.

On one hand, women with high levels of sterilization, high percentages of more than one pregnancy between January 2001 and July 2007, and larger parity than the desired number of children tend to have 
the following characteristics: high parity (three, four or more children); black, brown (who have not yet reached the desired number of children), or indigenous; residents in the North or Northeast regions; low levels of education (up to three years of schooling); and two or more unions. On the other hand, women with high levels of sterilization, low percentages of more than one pregnancy in the period, and lower parity than the desired number of children tend to have the following characteristics: cesarean section deliveries; birth using health insurance ("convênio") or direct out-of-pocket payments at private hospitals; and are married. More specifically, the cumulative percentage distributions of sterilized women by age at sterilization indicate that sterilization is more associated with type of delivery than with place of delivery.

A previous analysis suggested that a significant proportion of women might be getting sterilized after they reach the desired number of children and that they have not been spacing out the timing of their births as much as unsterilized women (Perpétuo and Wong 2009). The results of the present support this hypothesis by indicating that sterilized women have greater parity than the ideal number of children, while non-sterilized women have lower parity than the ideal number of children. Moreover, the findings of this paper illustrate that women who gave birth at public hospitals have similar parity to their desired number of children. Women who delivered at private hospitals and those who used their health insurance have parity below the desired number of children. Results also highlighted that women at private hospitals and those who used health insurance exhibit higher percentages of sterilization compared to women at public hospitals.

These findings could be a consequence of different patterns, which should be further investigated. One hypothesis is that on average, women at private hospitals and those who used health insurance might have not yet reached their ideal number of children, because they could be postponing childbearing to older ages. Another hypothesis is that high sterilization rates among women at private hospitals and for those who used health insurance might affect long-term levels of fertility rates in the country because of a lower parity than the ideal number of children. Possible effects of sterilization rates on fertility below the replacement level is an important topic for consideration.

One could argue that women are having forced sterilizations, which might cause regret following the procedure (Curtis et al. 2006; Fernandes et al. 2001; Ludermir et al. 2009; Machado et al. 2005; Vieira 2007). However, sterilized women have a greater parity than the ideal number of children. Data indicate that sterilization is higher among older women, women with a higher parity, as well as in areas of the highest fertility rates (North and Northeast). The female sterilization rates are also high for women who have parity lower than the ideal number of children, among those with cesarean deliveries, births at private hospitals, and are married. Since sterilization is harder to get in the public sector, women might be going to the private sector in order to get this procedure, in conjunction with a cesarean delivery (Barbosa and Knauth 2003; Caetano and Potter 2004; Carvalho et al. 2007; Costa et al. 2006; Lacerda et al. 2005; Osis et al. 2009; Potter et al. 2003).

The 1997 family planning law established restrictions for female sterilization in public hospitals for surgeries during cesarean deliveries, childbirth, and abortion. A major goal of the law was to prevent unnecessary cesarean deliveries, which would be performed followed by postpartum sterilizations. However, a large proportion of sterilization has still been occurring with cesarean deliveries, such as illustrated with the 2006 PNDS (Figure 1). Moreover, this data indicated higher rates of sterilization with direct-out-of-pocket payments at private hospitals and using health insurance ("convênio"). The interaction of type and place of delivery showed higher rates of sterilization with cesarean deliveries in private hospitals, public hospitals, and using health insurance. Cumulative percentage distribution of sterilized women by age indicated that even for women below 35 years of age, there is a high incidence of sterilization with cesarean deliveries in private and public hospitals compared to other groups. As previously discussed, women from higher socioeconomic groups usually use services in private hospitals. These facilities tend to have higher rates of cesarean sections (Hopkins et al. 2014). Higher levels of vaginal delivery are observed at the public sector (Hopkins et al. 2014), where women tend to be from lower socioeconomic groups. Thus, the 1997 family planning law seems to be preventing women from lower socioeconomic groups to have access to sterilization, creating inequalities in the access to contraception by socioeconomic status (Potter et al. 2003). 
One way to deal with this issue could be to alter the law in order to allow female sterilization in conjunction with vaginal delivery in public hospitals. The aim would be to attend a possible demand of Brazilian women in public hospitals who cannot afford this surgery in private hospitals.

At the same time, the high prevalence of sterilization in private institutions during cesarean sections should be a concern of the government. The current law might be incentivizing wealthy women to have cesarean sections in the private sector so that they can get sterilized following childbirth. The government should not only aim to implement policies to regulate the public sector, but also to encourage better services at private institutions. The government has to implement family planning programs with appropriate health care, guidance, and access to sexual and reproductive health services for women (Bilac and Rocha 1998; Carvalho et al. 2007; Costa et al. 2006; Giffin and Costa 1999; Miranda-Ribeiro and Simão 2009; Schor et al. 2000; Vieira et al. 2005; Vieira and Souza 2009). Access to more options relating to modern contraceptive methods must be provided, as well as appropriate medical follow-ups, which would prevent women from facing the financial burdens by themselves with high costs of sterilization and cesarean sections in the private sector.

The analysis of 2006 PNDS indicate a high prevalence of sterilization among certain groups of women who have not yet reached their desired number of children. For instance, among women who experienced a cesarean section, parity (1.8 children) is lower than ideal number of children (2.1) and 24.4 percent of them are already sterilized. Only 7.9 percent of women with vaginal delivery are sterilized. Women having childbirth with health insurance and at private hospitals have the highest sterilization rates and experience lower parity than the ideal number of children. The interaction of type of delivery with place of delivery indicates that parity is lower than ideal number of children among women having cesarean delivery with health insurance or at private hospitals. Sterilization rates are at the highest levels within these groups. Therefore, female sterilization should be discussed in the context of fertility below the replacement level, as one of its associated factors. Since sterilization is a permanent method, these findings might be an indication that the number of children ever born at the end of the reproductive period might stay below 2.1 children per woman, especially among sterilized women.

The main objective of this article was to understand the profile of female sterilization in Brazil. The results suggest some topics for future research. Future studies could continue evaluating how the incidence of female sterilization affects the use of other contraceptive methods. An important question is whether women would have decided for sterilization if they had other contraceptive options, comparing different socioeconomic contexts and regions within Brazil. Some of the studies cited above emphasize regret following sterilization. Further studies could analyze factors associated with the decisions of women to use different contraceptive methods with nationally representative data. This would be essential to better provide sexual and reproductive health services in the public and private sectors. Models of competitive risks could be used to develop this type of analysis. Finally, cohort studies could explore differences in the prevalence of female sterilization among women born in different times.

Funding: The open access publishing fees for this article have been covered by the Texas A\&M University Open Access to Knowledge Fund (OAKFund), supported by the University Libraries and the Office of the Vice President for Research.

Conflicts of Interest: The author declares no conflict of interest.

\section{References}

Amorim, Flávia Alfen, Suzana M. Cavenaghi, and José Eustáquio Diniz Alves. 2008. Mudanças recentes no uso de métodos contraceptivos no Brasil e na Colômbia: com especial menção à esterilização masculina e feminina. In Población y Salud Sexual y Reproductiva en América Latina. Edited by L. R. Wong. Rio de Janeiro: Asociación Latinoamericana de Población (ALAP), pp. 101-30.

Barbosa, Regina Maria, and Daniela Riva Knauth. 2003. Esterilização feminina, AIDS e cultura médica: os casos de São Paulo e Porto Alegre, Brasil. Cadernos de Saúde Pública 19: S365-S76. [CrossRef] [PubMed] 
Berquó, Elza. 1999. Ainda a questão da esterilização feminina no Brasil. In Questões de Saúde Reprodutiva. Edited by Karen Giffin and Sarah Hawker Costa. Rio de Janeiro: Editora Fiocruz, pp. 113-26.

Berquó, Elza, and Suzana Cavenaghi. 2003. Direitos reprodutivos de mulheres e homens face à nova legislação brasileira sobre esterilização voluntária. Cadernos de Saúde Pública 19: S441-S53. [CrossRef] [PubMed]

Berquó, Elza, Sandra Garcia, and Tânia Lago, eds. 2008. PNDS 2006, Pequisa Nacional de Demografia e Saúde da Criança e da Mulher: Relatório. Brasília: Ministério da Saúde.

Bilac, Elisabete Dória, and Maria Isabel Baltar da Rocha, eds. 1998. Saúde Reprodutiva na América Latina e no Caribe: Temas e Problemas. Campinas: Programa Latinoamericano de Actividades en Población (PROLAP), Campinas: Associação Brasileira de Estudos de População (ABEP), Campinas: Núcleo de Estudos de População (NEPO) da Universidade Estadual de Campinas (UNICAMP).

Brasil. 1996. Lei n. 9.263, de 12 de janeiro de 1996. Regula o parágrafo 7 do artigo 226 da Constituição Federal, que trata do planejamento familiar, estabelece penalidades e dá outras providências. Edited by Brasil. Brasília: Presidência da República do Brasil, Casa Civil, Subchefia para Assuntos Jurídicos.

Brasil. 2009. Pesquisa Nacional de Demografia e Saúde da Criança e da Mulher-PNDS 2006: Dimensões do processo reprodutivo e da saúde da criança. Brasília: Ministério da Saúde (MS) \& Centro Brasileiro de Análise e Planejamento (CEBRAP).

Caetano, André J., and Joseph E. Potter. 2004. Politics and female sterilization in Northeast Brazil. Population and Development Review 30: 79-108. [CrossRef]

Carvalho, José Alberto Magno de, Charles H. Wood, and Flávia Cristina Drumond Andrade. 2003. Notas acerca das categorias de cor dos censos e sobre a classificação subjetiva de cor no Brasil: 1980/90. Revista Brasileira de Estudos de População 20: 29-42.

Carvalho, José Alberto Magno de, Charles H. Wood, and Flávia Cristina Drumond Andrade. 2004. Estimating the stability of census-based racial/ethnic classifications: The case of Brazil. Population Studies 58: 331-43. [CrossRef] [PubMed]

Carvalho, Luiz Eduardo Campos de, Maria J. D. Osis, Jose G. Cecatti, Silvana Ferreira Bento, and Márcia B. Manfrinati. 2007. Esterilização cirúrgica voluntária na Região Metropolitana de Campinas, São Paulo, Brasil, antes e após sua regulamentação. Cadernos de Saúde Pública 23: 2906-16. [CrossRef] [PubMed]

Cavenaghi, Suzana, and José Eustáquio Diniz Alves. 2009. Fertility and contraception in Latin America: historical trends, recent patterns. In Demographic Transformations and Inequalities in Latin America: Historical Trends and Recent Patterns. Edited by Suzana Cavenaghi. Rio de Janeiro: Latin American Population Association (ALAP).

Costa, Nilma Dias Leão, Neir Antunes Paes, Paulo César Formiga Ramos, and Maria Célia de Carvalho Formiga. 2006. Desejo, intenção e comportamento na saúde reprodutiva: A prática da cesárea em cidade do Nordeste do Brasil. Revista Brasileira de Ginecologia e Obstetrícia 28: 388-96. [CrossRef]

Cunha, Antônio Carlos Rodrigues da, Miriam da Silva Wanderley, and Volnei Garrafa. 2007. Fatores associados ao futuro reprodutivo de mulheres desejosas de gestação após ligadura tubária. Revista Brasileira de Ginecologia e Obstetrícia 29: 230-34. [CrossRef]

Curtis, Kathryn M., Anshu P. Mohllajee, and Herbert B. Peterson. 2006. Regret following female sterilization at a young age: A systematic review. Contraception 73: 205-10. [CrossRef]

Fernandes, Arlete Maria dos Santos, Maurício De Souza Arruda, Marco Antônio Rocha Palhares, Nei Danilo Benetti Júnior, and Cristiane Menabo Moreira. 2001. Seguimento de mulheres laqueadas arrependidas em serviço público de esterilidade conjugal. Revista Brasileira de Ginecologia e Obstetrícia 23: 69-73. [CrossRef]

Fonseca Sobrinho, D. 1993. Estado e População: uma História do Planejamento Familiar no Brasil. Rio de Janeiro: Editora Rosa dos Tempos, Rio de Janeiro: Fundo de População das Nações Unidas (FNUAP).

Giffin, Karen, and Sarah Hawker Costa. 1999. Questões da Saúde Reprodutiva. Rio de Janeiro: Editora Fiocruz.

Godecker, Amy L., Elizabeth Thomson, and Larry L. Bumpass. 2001. Union status, marital history and female contraceptive sterilization in the United States. Family Planning Perspectives 33: 25-41, 49. [CrossRef]

Hopkins, Kristine. 2009. Getting sterilized in Brazil: stories of sucess and failure. In Qualificando os Números: Estudos sobre Saúde Sexual e Reprodutiva no Brasil. Edited by Paula Miranda-Ribeiro and Andréa Branco Simão. Belo Horizonte: Associação Brasileira de Estudos Populacionais (ABEP) \& Fundo de População das Nações Unidas (UNFPA), pp. 167-83. 
Hopkins, Kristine, Ernesto Friedrich de Lima Amaral, and Aline Nogueira Menezes Mourão. 2014. The impact of payment source and hospital type on rising cesarean section rates in Brazil, 1998 to 2008. Birth 41: 169-77. [CrossRef]

IBGE. 2012. Censo Demográfico 2010: Resultados Gerais da Amostra. Rio de Janeiro: Instituto Brasileiro de Geografia e Estatística (IBGE).

Janowitz, Barbara, James E. Higgins, Walter Rodrigues, Jose Marie Arruda, Jason B. Smith, and Leo Morris. 1985. Sterilization in the Northeast of Brazil. Social Science E Medicine 20: 215-21.

Lacerda, Marisa Alves, Paula Miranda-Ribeiro, André Junqueira Caetano, and Carla Jorge Machado. 2005. Mensuração e perfis de demanda insatisfeita por contracepção nos municípios de Belo Horizonte e Recife, 2002. Revista Brasileira de Estudos de População 22: 113-29.

Leone, Tiziana, and Andrew Hinde. 2005. Sterilization and union instability in Brazil. Journal of Biosocial Science 37: 459-69. [CrossRef] [PubMed]

Ludermir, Ana Bernarda, Kátia Maria de Melo Machado, Aurélio Molina da Costa, Sandra Valongueiro Alves, and Thália V Barreto de Araújo. 2009. Tubal ligation regret and related risk factors: findings from a case-control study in Pernambuco state, Brazil. Cadernos de Saúde Pública 25: 1361-68. [CrossRef] [PubMed]

Machado, Katia Maria de Melo, Ana Bernarda Ludermir, and Aurélio Molina da Costa. 2005. Changes in famly structure and regret following tubal sterilization. Cadernos de Saúde Pública 21: 1768-77. [CrossRef]

Minella, Luzinete Simões. 2012. Esterilização feminina: temáticas e abordagens em periódicos científicos no Brasil (2000-2010). In 18th Meeting of the Brazilian Association of Population Studies. Edited by ABEP. Águas de Lindóia: Associação Brasileira de Estudos Populacionais (ABEP).

Miranda-Ribeiro, Paula, and Andréa Branco Simão. 2009. Qualificando os Números: Estudos sobre Saúde Sexual e Reprodutiva no Brasil. Belo Horizonte: Associação Brasileira de Estudos Populacionais (ABEP) \& Fundo de População das Nações Unidas (UNFPA).

Molina, Aurelio. 1999. Laqueadura tubária: situação nacional, internacional e efeitos colaterais. In Questões da Saúde Reprodutiva. Edited by Karen Giffin and Sarah Hawker Costa. Rio de Janeiro: Editora Fiocruz, pp. $127-45$.

Osis, Maria José Duarte, Anibal Faúndes, Maria Helena de Sousa, Graciana Alves Duarte, and Patricia Bailey. 2003. Fecundidade e história reprodutiva de mulheres laqueadas e não laqueadas de Campinas, São Paulo, Brasil. Cadernos de Saúde Pública 19: 1399-404. [CrossRef]

Osis, Maria José Duarte, Luiz Eduardo Campos de Carvalho, José Guilherme Cecatti, Silvana Ferreira Bento, and Karla Simônia de Pádua. 2009. Atendimento à demanda pela esterilização cirúrgica na Região Metropolitana de Campinas, São Paulo, Brasil: Percepção de gestores e profissionais dos serviços públicos de saúde. Cadernos de Saúde Pública 25: 625-34. [CrossRef] [PubMed]

Perpétuo, Ignez Helena Oliva. 1998. Contracepção e declínio da fecundidade na Região Nordeste. Revista Brasileira de Estudos de População 15: 43-56.

Perpétuo, Ignez Helena Oliva, and Simone Wajnman. 2003. Socioeconomic correlates of female sterilization in Brazil. In Poverty, Fertility and Family Planning. Edited by M. E. Cosio-Zavala. Paris: CICRED, pp. 311-33.

Perpétuo, Ignez Helena Oliva, and Laura Rodríguez Wong. 2009. Desigualdade socioeconômica na utilização de métodos anticoncepcionais no Brasil: uma análise comparativa com base nas PNDS 1996 e 2006. In Pesquisa Nacional de Demografia e Saúde da Criança e da Mulher_PNDS 2006: Dimensões do Processo Reprodutivo e da Saúde da Criança. Edited by Brasil. Brasília: Ministério da Saúde, Brasília: Centro Brasileiro de Análise e Planejamento (CEBRAP), pp. 87-104.

Potter, Joseph E. 1999. The persistence of outmoded contraceptive regimes: The cases of Mexico and Brazil. Population and Development Review 25: 703-39. [CrossRef]

Potter, Joseph E., Carl P. Schmertmann, and Suzana M. Cavenaghi. 2002. Fertility and development: Evidence from Brazil. Demography 39: 739-61. [CrossRef]

Potter, Joseph E., Ignez H. O. Perpétuo, Elza Berquó, Kristine Hopkins, Ondina Fachel Leal, Maria Celia de Carvalho Formiga, and Marta Rovery de Souza. 2003. Frustrated demand for postpartum female sterilization in Brazil. Contraception 67: 385-90. [CrossRef]

Potter, Joseph E., Carl P. Schmertmann, Renato M. Assunção, and Suzana M. Cavenaghi. 2010. Mapping the timing, pace, and scale of the fertility transition in Brazil. Population and Development Review 36: 283-307. [CrossRef] 
Schor, Néia, Andrea Felicissimo Ferreira, Vera L. Machado, Ana Paula França, Kátia C. M. Pirotta, Augusta Thereza de Alvarenga, and Arnaldo Augusto Franco de Siqueira. 2000. Mulher e anticoncepção: Conhecimento e uso de métodos anticoncepcionais. Cadernos de Saúde Pública 16: 377-84. [CrossRef]

Vieira, Elisabeth Meloni. 2007. O arrependimento após a esterilização cirúrgica e o uso das tecnologias reprodutivas. Revista Brasileira de Ginecologia e Obstetrícia 29: 225-29. [CrossRef]

Vieira, Elisabeth Meloni, and Luiz de Souza. 2009. Access to surgical sterilization through the National Health System, Ribeirão Preto, Southeastern Brazil. Revista de Saúde Pública 43: 398-404. [CrossRef]

Vieira, Elisabeth Meloni, Suzi Volpato Fábio, Wagner Gueleri, Miriam Pinheiro Picado, Elizabeth Yoshinaga, and Luiz de Souza. 2005. Características dos candidatos à esterilização cirúrgica e os fatores associados ao tipo de procedimento. Cadernos de Saúde Pública 21: 1785-91. [CrossRef]

Wood, Charles H., and José Alberto Magno de Carvalho. 1994. Categorias do censo e classificação subjetiva de cor no Brasil. Revista Brasileira de Estudos de População 11: 3-17.

(C) 2019 by the author. Licensee MDPI, Basel, Switzerland. This article is an open access article distributed under the terms and conditions of the Creative Commons Attribution (CC BY) license (http://creativecommons.org/licenses/by/4.0/). 